\title{
Sport and democracy: Philosophical trends and educational challenges in contemporary society
}

\section{Deporte y democracia: Corrientes filosóficas y retos educativos en la sociedad contemporánea}

\section{Francisco Javier López Frías ${ }^{1}$, Emanuele Isidori ${ }^{2}$}

1 Facultad de Filosofía. Universidad de Valencia. España.

2 Faculty of Motor Sciences. University of Rome "Foro Itálico". Italy.

CORRESPONDENCIA:

Francisco Javier López Frías

\begin{abstract}
This paper argues that sport may be a useful educational tool for our liberal-democratic societies. To demonstrate this claim, we first analyse the controversial issue of whether or not sports are serious activities linked to the larger society and their values. Second, we argue that sport has always had such a connection with society since ancient times. Third, we show that the origin of both politics and philosophy was linked to several forces and attitudes pertaining to sport. Fourth, we show that such forces and attitudes are still at the core of contemporary sport. As a result, we defend that we can still use sports to enhance the quality of our liberal-democratic societies.
\end{abstract}

Key words: Sport, philosophy, democracy, education, society.

\section{Resumen}

Este artículo defiende que el deporte puede ser una herramienta educativa útil para nuestras sociedades democrático-liberales. Con el fin de demostrar esta posibilidad, primero analizamos la cuestión de si el deporte es una actividad seria que está ligada a nuestra sociedad y a sus valores. En segundo lugar, defendemos que el deporte siempre ha tenido dicha conexión desde tiempos antiguos. Tercero, mostramos que tanto el origen de la política como el de la filosofía estuvo motivado por fuerzas que pertenecieron, en principio, al deporte griego. Por último, mostramos que estas fuerzas aún se encuentran a la base de nuestro deporte contemporáneo. Por lo tanto, aún pueden ser usadas para mejorar la calidad de nuestras sociedades democrático-liberales.

Palabras clave: Deporte, filosofía, democracia, educación, sociedad. 


\section{The ludic and the serious nature of sports: A pedagogical challenge}

There are two main issues at root of the philosophy of sport since its birth at the beginning of the 20th century. First is the discussion of whether or not sport is a serious practice-or a trivial one-within society. Second is the relationship between sporting values and the larger society. Johan Huizinga, the famous Dutch historian, explored both issues in 1939 in his Homo ludens, which is one of the most fruitful humanistic analyses of sport in History. This book's main thesis is that the childish nature of sports, conceived as games, turns them into isolated practices that are so artificial that they have nothing to do with the relationships observed in the larger society. Sport involves a world in which everyday habits, values, and the like are suspended; sport is, thus, a trivial activity that we practice just for fun. However, Huizinga claims that such a ludic and isolated nature of sports and games does not override the possibility that sporting values have some influence on societies' values. This is the reason why the Belgium philosophers of sport Jan Tollener and Paul Schotsmans identify sport as "the most important of the trivial subjects in the world" (2013, p. 21).

According to Huizinga, cultures have ludic elements which influence human beings' interpretation of life and their conception of good. For example, there was no clear-cut distinction between the ludic aspect of life and the serious one in ancient culture; both sides were intrinsically interwoven. For instance, following Jaeger (1944), ancient Greeks tried to establish a distinction between paidiá and agón. The former concept was employed to talk about childish games, whereas the latter had a much wider sense which could be found in every social realm. However, as Jaeger claims, the limits between these two concepts were blurred. They were always changing, so ancient Greeks could not establish a set distinction between agón and paidiá. For instance, Plato used the term paidiá in reference to religious ceremonies, which cannot be conceived as childish activities. So even the most ludic activities are linked to social practices, which play an important role in the human task of making sense of reality.

In line with this function of Greek sports, Huizinga wonders whether our contemporary ludic activities still have this potential or not. However, his response is negative. When specialisation and professionalisation became an essential part of sports in the 19th century, as explained so well by Allan Guttmann (1978), they downplayed the ludic element of sports to such an extent that they cannot be conceived as ludic activities anymore; the process of modernising sports has removed their ludic nature. Contemporary sport has nothing to do with ancient Greek sports' function of giving meaning to reality. Thus, using Max Weber's terminology, sport has been disenchanted to such an extent that its organic connection to the larger society has been removed.

Only amateur sports keep this organic connection to society. This was the core idea of the pedagogical proposal called "muscular Christianity", which emerged in the 19th Century with the aim of introducing sports in schools. The purpose of this proposal was to use sports and physical activity as a tool to teach diverse values that were not just useful to the individuals (like taking care of oneself), but also to the larger society. The so-called "father of the Olympic movement" Pierre De Coubertin embraced this theory to create our modern Olympic Games. Moreover, this pedagogical proposal is the foundation of the pedagogical theories from which philosophy of sport emerged during the 1970s.

As the philosophy of sport emerged as a branch of the pedagogy of sport, the issue concerning the meaning of sport's values and their relationship to the larger society became the main worry for sport philosophers. Thus, they have been discussing Huizinga's claims ever since. For example, Paul Weiss argues that modern sport does have pedagogical value. According to him, contemporary sport is the place where individuals meet the values and excellencies of adult everyday life for the first time. In line with this idea, Weiss, and those who follow his ideas, shows, first, that sport is not a trivial activity within society and, second, that modern sports have more to do with how society works than Huizinga claimed.

However, as Mike McNamee (1998) and Robert S. Kretchmar (2007) have pointed out, the philosophical background of these philosophers of sport is AngloAmerican philosophy, that is to say, Analytic philosophy and Utilitarianism. Thus, sport philosophy's methodology has been reduced to such philosophical proposals, which, according to Kretchmar, have led us to a "dead-end" in the philosophy of sport. So we are always stuck at the same point in some of the debates in this discipline. This paper will defend that the debates on the pedagogical nature of sport and its relationship to the larger society have reached a dead-end. In so doing, we will argue that we need to complement Anglo-American philosophy of sport with hermeneutics in order to clarify and bring some light to these discussions. In that way, we will argue that typically hermeneutic issues -and not analytic issues- have been at the root of the philosophy of sport since its very beginning. 


\section{Bringing hermeneutics into the philosophy of sport}

Hermeneutics has been present in the philosophy of sports for a long time. Nonetheless, Anglo-American philosophers did not realise this since they rarely utilise the term "hermeneutics". Nonetheless, the normative theory that is arguably the most widespread in the philosophy of sport is called "interpretivism". "Interpretation" is one of the key terms in hermeneutics. Moreover, the philosophers of sport who developed such a normative theory, Robert L. Simon (2000) and John S. Russell (1999), grounded their ideas in those by hermeneutic authors like Alasdair MacIntyre and Ronald Dworkin. For example, they borrowed MacIntyre's concept of "social practice" to describe the nature of sport. In this way, the main purpose of interpretivist philosophy is to understand what the intrinsic values, goods, and excellencies of sports are like.

However, interpretivist analyses of sport are not hermeneutic enough. As William J. Morgan has claimed (2012), interpretivism has reduced the nature of sport to a unitary principle which tries to capture the essential logic of sports. For example, along with Simon (2010), many philosophers, such as Cesar R. Torres (2011) and Mike McNamee (2008), have argued that sport is a quest for physical excellence. This section addresses the reasons for which such interpretivist proposals are not hermeneutic enough.

Following Gadamer's critique of the philosophies of Schleiermacher and Dilthey (Gadamer, 1975, p. 291-292), the task of hermeneutics is not to find a single principle or a unitary structure in accordance to which we give an interpretation of reality. The spirit of hermeneutics is not reductive. It embraces complexity and tries to understand it as a whole. Thus, for sports to be analysed in a hermeneutic way, complexity cannot be reduced to one single principle, but it has to be confronted by interpreting the very complex net of elements that are always shaping the reality of sports. According to Gadamer, this interpretation has a cyclical nature. In Heidegger's words, this cyclical nature is not to be reduced to the level of a vicious circle or even of a circle which is merely tolerated. A positive possibility of the most primordial kind of knowing is hidden in the circle. To be sure, we genuinely take hold of this possibility only when, in our interpretation, we have understood that our first, last, and constant task is never to allow our fore-having, fore-sight, and foreconceptions to be presented to us by whim and popular conceptions, but rather to make the scientific theme secure by working out these fore-structures in terms of the things themselves (Heidegger, 1962, p. 195).
According to Heidegger, there is no logical culmination of the process of interpretation. Nonetheless, during the cyclical movement of understanding, we discover the facticity (or basic hermeneutic preconditions) of the issue at stake (Gadamer, 1975, p. 294). So, hermeneutics «reflects on the historical and cultural preconditions of [a particular] experience and seeks to discern in it something of the predicament, character, and mode of being of those who "undergo" such experience [...] by deepening our sense of what underwrites and is implied by such experience» (Davey, 2006, p. 1, 5). This hermeneutical reflection makes us aware that we are finite beings surrounded by other finite beings to whom we are inextricably bound. Experience is never carried out in the void; rather, as Hegel showed in his Phenomenology of Spirit, it is inseparable from the recognition of the other and otherness.

Following the basic tenets of hermeneutics explained so far, this paper would offer a possible application of hermeneutics to the philosophy of sport. The analysis of the concept "contest" ("agón") will be its starting point. Such a concept will be understood by conceiving of sport as one of the parts of the "text" conformed by our social life (Isidori, 2011, p. 95). A proper understanding of sports has to show their dependence upon the cultural and social elements that lie outside them. A philosophy of sport thought of in this way must answer the following questions:

What are the communitarian, social, political, ethical and educative implications of sports, understood as a human and a cultural practice? Can we think of sports aside from an ethics of responsibility? How is it possible to rethink sports beyond the positions taken for granted, the prejudices, and the stereotypes that characterise them, in order to turn sports into practices which respect equity, justice, and the equality and rights of minorities and those marginalised individuals who deserve to be recognised and accepted by society? How could we turn sports into a tool to change and transform society for the better? (Isidori, 2011, p. 96).

The quotation above shows that the key issues for our hermeneutic analysis of sport go beyond the interpretation of the intrinsic logic of sport. In the remainder of this paper, we will attempt to show the interrelationships existing between sporting contests and the most important social practices in ancient Greek societies: religion, politics, and philosophy.

\section{Sports and conflict resolution problem solving: Religion, peace, and philosophy}

Philosophical attitude emerges when there is a vital problem that troubles us. This problem focuses 
our attention in a way that is urgent for us to solve it. Philosophy grew out of a feeling of amazement and curiosity that Greeks called thaumázein. However, tháuma has less to do with the amazement and more with the wondering of the human being who wants to understand the "who", the "what", and the "why" of a given event.

We argue that both philosophy and sports grew out of this feeling of wonder, which Joan-Carles Melich (1996) took to be at the roots of philosophy. Along with this idea, Heather L. Reid, following Stephen G. Miller's thesis, argues that Greek sport could inspire, and even boost, the emergence of philosophy, especially due to the religious meaning that ancient Greeks placed on sport (Reid, 2011, p. 11-22; Tuncel, 2013, p. 20-21). To prove her thesis, Reid highlights the sacrificial function of Greek sporting events to demonstrate their religious nature.

Ancient Greeks conceived their festivals as a commercial exchange, as Theodor W. Adorno and Max Horkheimer show in the Dialectic of the Enlightenment. Greeks offered diverse goods and belongings to the gods in exchange for protection and divine favours. Thus, they needed to know the preferences of the gods -to "get inside their minds"so they could offer them their favourite goods in order to get a better prize.

According to Reid, sports, conceived of as sacrificial rites, did not offer material goods but excellent individuals. Thus, it was the victor of the most important athletic contest, the foot race in Olympia, who was in charge of lighting the Olympic flame ("the sacrificial flame") as a sign of self-sacrifice. Consequently, the most excellent person -the victor-, was offered to the gods; he was given in symbolic sacrifice. This is the reason why the Greeks thought that the victors did not deserve material prizes; rather, it was enough for them to have the honour of being offered in sacrifice to the gods. Was physical excellence the only thing that agonistic contests offered to the gods?

Reid responds to this question by showing that gods looked for a wider set of characteristics in athletes (Reid, 2011, p. 27-29). They were looking for something beyond being mere victors. In fact, Greek gods were so involved in human affairs, as shown by the incident of Patroclus' funeral games, that they intervened in the course of the contest to promote the victory of their favourite athletes. Gods chose the athlete they wanted to be the "symbolic sacrifice". To do this, they ranked athletes according to their humility, the respect that they showed to the other and to the rules (which were the impartial measuring stick), and their public performance. The chosen ones, like Heracles, were the heroes, who were considered to be demigods (half mortal, half-immortal human beings). Therefore, engaging in the sporting contest was the way for the athletes to struggle to reach the unknown, the world of the Olympic gods.

Reid argues that sporting contests (based on physical features) paved the way for "philosophical contests" (whose nature was intellectual). Whereas the participation in the physical contest was the way for Greek athletes to meet their gods, pre-Socratic philosophers thought of philosophical reflection as another way to know the arché of the world (to get in touch with the gods and capture their nature). Moreover, during this "philosophical quest for the gods", Greek philosophers embodied the very same set of features as excellent athletes: humility, impartiality, and publicity. They made arguments for humility, impartiality, and built upon public reasoning open for discussion. For Reid, this proves that the very elements that characterised the sporting contest were at the roots of Greek philosophy. Besides, as was pointed out before, both disciplines emerged from vital problems that human beings faced: the search for meaning.

As the famous archaeologist and historian Stephen G. Miller shows, religious and sporting practices did not simply have sacrificial and existential value; rather, they also had an ethical-social function: pacific problem solving (Miller, 2004). Miller's studies show that Greeks always established a connection between sports (social dimension of life) and religion (spiritual dimension). Both activities were a way to shape the behaviour of Greek citizens. For instance, the Olympics were celebrated in honour of the gods and were thereby utilised to substitute war for peace during the time in which the event was celebrated.

Athletes, accompanied by their families, friends, and coaches, were brought together in the same place to compete against each other as equals; political identities and rivalries disappeared. The Games were a means to promote cross-cultural dialogue (Miller, 2004 , p. 250). Miller casts some doubt over this pure of an apolitical conception of the Games. He argues that city-states (póleis) used athletes to compete against each other, so the glory of their athletes was identified with the one polis. Then, Greek agonistic contests were a way for the city-states to test their superiority over the others. However, this fact does not question the claim that Greek sports had to do with peace. For instance, the ancient Olympics were never cancelled. On the other hand, our modern Olympic Games have been cancelled three times. Despite Miller's doubts regarding the apolitical nature of sporting events, we argue that his claim does not 
downplay the "peacemaking nature" of sport. Sport is not a magical tool which will immediately produce peace in the world; nonetheless, it has some positive forces on the basis of which peace could be promoted (Wachter, 2002, p. 446). Some of these positive forces linked to sport will be analysed in section 8 .

\section{Sports and the ethics of hospitality}

Greek sporting contests were thought of as a way to deal with the ethical-political problem of how to solve people's disputes pacifically. Can they all "live (compete) under the same roof" without killing each other? What are the limits of individuals' egoistic selfdevelopment? To what extent should they compete with each other? What are the benefits of such competition? Can competition be turned into pacific cooperation? Greek sporting contests can be conceived of as a microcosmos of what to do in the larger society. This is the reason why they were structured in accordance with one of the most sacred and important values in Ancient Greek culture: hospitality.

Ancient sports were closely linked to the rites of hospitality, peace, hosting, housing, and communicating between foreigners (the practice of the exchange of xenia - gifts- between foreigners of diverse polis during the Games proves this claim). Competitors were brought together in the same city, Elis, before the Games to train, follow their diets, to show their skills, to be scouted to participate in the Games in Olympia, and to learn the rules of both the city and the contest. The city of Elis had the duty of hosting them. In exchange, they had to learn how to behave properly to pay tribute to the Games and the city by paying attention to the lessons of the hellanodikai -"guardians of the law".

This is a two-way relationship: the city had the duty of hosting the athletes and they had to abide by the rules of the new house of which they were part. As we explained before, the hellanodikai taught these rules and obligations to the athletes with the aim of turning training and physical effort into the most important activities of the athletes. Thus, athletes had to take the following oath during the procession from Elis to Olympia:

If you have worked so as to be worthy of going to Olympia, if you have done nothing indolent or ignoble, then take heart and march on; but those who have not so trained may leave and go wherever they like (Miller, 2003, p. 9).

Only those who observe the rules of the "house" are worthy of going to Olympia. According to this, Greek sport was always linked to the original meaning of the word "ethics". This word comes from the Greek word "êthos", which means both "costumes" and "house" or "the way to behave in the house". As Greek ethics has to do with the house, it is mainly related to face-toface relationships and to the way in which we should host a foreigner and respect the social and religious rules of the places we visit. In fact, the pediment of the temple of Zeus at Olympia shows Apollo trying to solve the dispute among centaurs and Lapiths, which was essentially a problem of bad behaviour in the house.

The details about this battle are the following. Pirithoüs, King of the Lapiths, and Hippodamia were getting married. Centaurs were invited to the event because they were relatives of the bride. They drank too much so they tried to kidnap and rape the bride. In so doing, they clearly broke the laws of hospitality and offended their host. Thus, the founding myth of Olympia, the archetypical city of Greek sport, is mainly related to the behaviour in the house, a myth based on hospitality, hosting, and acceptance of others. Therefore, as the most important city of Greek sports was built upon a myth related to hospitality, the Greek athletic festival was also essentially linked to it.

As we have shown in sections 3 and 4 , there was a clear relationship between sports, the polis, and religious and social laws. Thus, we wonder whether sports and politics had common roots in ancient Greek. In the next section, we will explore the potential relationship between Greek politics and sports in order to expose what those common roots could be. In fact, politics, as Aristotle stated, is the skill of governing the "big house", which is what the city (pólis) is.

\section{Greek sports and the pólis}

The Olympics were held for the first time in 772 BC. Philosophy was born in the 7th century BC and democracy was created in Athens in the 5th century BC. As Greek sports appeared earlier in time than democracy and philosophy, many authors, such as Reid and Miller, claim that it is plausible that some of the main concepts in sport were translated into both politics and philosophy. In this paper, we defend a weaker thesis, inspired by Guttmann's analysis on the emergence of modern sports, which argues that there was a common social consciousness, highly marked by the agonistic spirit, from which sports, philosophy, and politics emerged. However, we cannot defend that there was a causal relationship between sports and other activities since there is no historical evidence to 
support this. We can only show the interconnections existing between the three aforementioned disciplines by analysing their origins.

According to David J. Philips (2003, p. 197-201), Greek sport was always intrinsically linked to politics. Since their very beginning, the Games celebrated the unity of the diverse póleis and the things that they had in common -regardless of their differences. Only differences produced by physical skills were accepted. However, competition used to go beyond this assumption. The contest was not just about athletes who competed to show their physical excellence, it was also about diverse polis struggling for recognition and glory. Thus, Philips quotes Jennifer Neils' works on Greek festivals. For instance, she argues that Athenians conceived their games and festival as a way to show the excellencies of the city:

In its inclusiveness, it exemplified the city's participatory democracy; in its contest, it demonstrated the competitive spirit of its people; with its prizes, it displayed the skills of its artisans and the wealth of its produce; and above all, it celebrated Athena as the divine protectress of a glorious city. (Philips, 2003, p. 202).

City-states adopted athletes who were originally from other places to use them as a tool to gain honour. These athletes received special treatments from the city such as free meals for the rest of their lives and tax and public services exemptions. Furthermore, many politicians used sports as a tool to achieve more power. For instance, Philip II of Macedon presented himself as the main defender of the Olympic ideal to get more allies and political power (Miller, 2004, p. 224).

The history of modern Olympics is also full of cases of political exploitation of them, such as, for example, the Nazi Games held in Berlin in 1936. However, this paper goes beyond pure historical facts to show the linkage between sports and politics; as such, we will attempt to understand the social meaning of the Greek sporting contest by appealing to the spirit which animated it: the agonistic one.

Following Thomas F. Scanlon, we define the agón as "a contest characterized by an all-out desire to win, the extreme effort to do so, high esteem for success, fame for the victor, and the recognition of the mortal and physical limitations of the defeated" (Scanlon, 2002, p. 275). Greek athletes were animated by an agonistic spirit which moved them to desire to outperform the opponents, to excel for show, to be superior, and, lastly, to attain fame. In so doing, they became immortal by being remembered as heroes after their death.
As Yunus Tuncel claims, following Jacob Burckhardt's thesis on the vital role played by the agón in ancient Greece, the Greek society was an agonistic society; agón was at the root of every single Greek social practice (Tuncel, 2013). Agón was thought of as an instrument of paideia, which provided socialisation in public life, apprenticeship in civic values, and places for expressing social order (Scanlon, 2002, p. 15). Thus, as Greek sports embodied the spirit of the agón, they were a kind of paideia that could directly affect behaviours in non-athletic endeavours. One such realm was politics.

The Greek word agón is derived from the lexeme "*-ag" which is also contained in the word "agorà", which means "square", and the place where people met together to participate in public events like religious festivals, political and philosophical debates, economic exchanges, and the like. So, the agorà was the core of communitarian life in ancient Greece. As both agón and agorà are derived from the same lexeme, they are essentially related.

Ancient Homeric heroes formed a circle (copying the shape of the agorà) when they had to discuss, fight, confront, dialogue, compete, give their opinion, evaluate, judge, think about strategies, choose a leader, and the like. They looked at each other's faces inside the circle and they recognised each other as equal human beings; they were all (as equal parts of the circle) homoioi, they spoke the same language, and they understood each other. None of them was the absolute leader. There was a member who was in charge of leading the conversation because he had proven to be the best in the group (a princeps inter pares). Thus, the circle (conceived as an agorà) was the place that showed their excellence and physical strength. Such a circle formed by the heroes illustrates the nature of the Greek agón: it was the way for excellent individuals to excel for show and to show their self-sufficiency while strengthening relationships with others. As Scanlon claims, these two aims, which appear at first to be antagonistic, were reconciled in the sporting agón.

Aristotle's political philosophy also tried to reconcile these very two aims located at the basis of the sporting agónes. Arguably, Aristotle's famous sentence that "a human being is by nature a political animal» (Aristotle, 1998, 1253a, p. 7-15) attempts to reconcile individuals' egoistic self-sufficiency and communitarian bonds. By conceiving of human beings as essentially political animals, Aristotle links human self-development (or individual prospering) to the necessary existence of the community since «anyone who is without a city-state, not by luck but by nature, is either a poor specimen or else superhuman» (Ibid.). 
Only a beast or a god can live without society. Human beings can only live and achieve their goal within a society. Moreover, as they have speech, they can make clear what is just or unjust and set rules and principles to organize social cooperation.

\section{The "agonistic" roots of democracy: The rules that guided the contest}

By looking at the rules that structured both democracy and sports in ancient Greece, we can better understand the possible interrelationship between these two practices and the spirit of the agón (Tuncel, 2013). As demonstrated, both democracy and sport are primarily based on confrontation practiced in accordance with several shared principles and a common discursive framework. For example, both citizens and athletes engaged in their practices as equals among equals and abided by the same set of principles so their competition could be measured in the same terms. This idea of publicity is at the basis of democracy; every citizen is equal before the law in democratic societies.

Equality is not the only democratic concept that emerged from sports. Rather, sports also show that we all are free. Athletes use the medium of the contest to freely express their personality and physical abilities. However, this freedom is not absolute, but rather it is linked to the freedom of the other participants; they abide by the rules and respect the opponent. We all are reciprocally interconnected in a way that we must always take into account the existence of others. Humans are individualistic and communitarian beings at the same time.

To further explore the aforementioned idea of a common set of principles shared in every contest, along with Miller's studies, we will analyse the diverse principles that guided agonistic contests - philosophical, sporting, or political. In fact, this sharing of principles is also found between our modern sports and politics. For instance, as Claudia Pawlenka shows (2005), Rawls used the equal conditions that make sporting contests possible to think about and illustrate his theory of justice.

The principles that philosophical, sporting, and political contests shared were the following:

1) According to Miller, the concept of isonomía was the most important contribution of athletic contests. Such a concept means that all the participants are equal before the law (Miller, 2004, p. 232). The graphic way to show such equality among athletes was to make them compete naked. Competing naked meant removing every type of difference between athletes.
Thus, it did not matter whether an athlete was rich or poor, whether he was born in Athens or Corinth. The important thing was that all of them had the same chance to win. «The participants in the gymnikos agon [were] democrats striving to excel with their beings, not their possessions» (Miller, 2004, p. 233). In fact, some historians have claimed that the first winner of the Games was a cook. As long as the athletes were staying in Olympia, they were under the same rulesthose rules that the helladonikai taught them in Ellis.

2) Isegoría is the second principle on which we want to focus. This principle belongs also to the vocabulary of democracy and it refers to have an equal access and right to participate in the contest. Thus, in Greek democracy, isegoría meant the right that every Greek citizen had to speak and defend his opinion in the agora.

3) Isokratía is the third concept at which we will look. Such a principle is linked to the Latin verb "possum", which means, "having the possibility of doing something". Given our particular contexts, isokratía meant that all athletes had the required capabilities and strength to become victors in a given contest. If we translate this concept into democratic terms, then it means that all citizens should have the same opportunities to be able to participate in public life.

This set of common principles were publicly shared and known, so the group of people who got together to listen to a speech or to watch a sporting contest were intrinsically linked to the agonistic contest. Agónes provided socialisation in public life, apprenticeship in civic values, and places for expressing social order. Citizens were inspired by the athlete's spirit of selfsacrifice and struggle. As Lucian Solon stated:

[At athletic festivals, the spectator's] zeal for the athletic events is thereby increased if they see the best among the competitors honoured and proclaimed as victors in the midst of the assembled Greeks [...] The prizes then [...] are not small, namely praise from the spectators, to become most distinguished, and to be pointed out as one thought to be the best among equals. Therefore many of the spectators who are still of the age to participate in athletics will go away from such experiences with an inordinate desire for excellence and hard work. (Scanlon, 2002, 16).

Athletes exhibited their excellence in sporting contests (areté), and they exemplified values and virtues which were at the core of ancient Greek societies. In so doing, they were admired and became role models for their society. For example, as Thomas F. Scanlon states, the figures of Heracles, Eros, and 
Hermes were present in every Greek gymnasium because they exemplified a different social benefit (Scanlon, 2002, p. 12). Hermes exemplified eloquence, Heracles represented strength, and Eros epitomised communication. People embodied these valuable human qualities by engaging in sports. According to our interpretation of Greek sporting contests, the three abovementioned principles that structure the agonistic contest (isonomía, isegoría, and isokratía) could also be learned by Greeks through sports. In line with this educational potential of Greek sports, contemporary sport is also conceived of as expressing and fostering the constitutive values of our democraticliberal societies, especially, freedom and equality.

\section{Sports and the political project of Modernity}

In accordance with Peter J. Arnold and following the three driving principles of sporting contests, we divide the essence of democracy into three parts. Democracy is:

a) "By the people": The government expresses and embodies the will of those governed.

b) "For the people": Democratic procedures such as making decisions, passing laws, and voting are in the best interest of the people as a whole.

c) "Of the people": People from every kind of social background compose the government.

According to Arnold, there is an underlying principle to these three ideas. This is the idea that every human being is worthy of dignity and respect. Such value needs to be protected by conferring rights to the individuals on the basis of the principles of freedom and equality. These are the core principles at the basis of our democratic-liberal societies whose main aim is to make human beings prosper. It could be argued that these goals and principles are too far from the reality of our neo-liberal societies, which tend to overemphasise freedom over other values. However, as Jürgen Habermas claims (1997, p. 51), modernity is still an unfinished project. So long as this is so, we have to struggle to realise its principles in order to better our world. The promotion of societies that are both more egalitarian and have freer individuals is at the root of our societies, and it should likewise be so in the case of modern sports.

Pierre De Coubertin, by following the teachings of the muscular Christianity, tried to use modern sports as a tool to promote both equality and freedom. According to him, sports are a perfect model for democratic societies; we need to create a "sporting republic". In such a model, inspired by the principles that guide sporting competitions, there are neither privileges nor injustices. Victors are decided on the basis of their effort, and talent, and their achievements are temporary. This is the reason why Greek athletes received a crown made from olive leaves. Such a plant material illustrates the temporary character of the victory. Positions were always changing and being renovated, those who wanted to keep them needed to struggle more. The motto was: «new contests, new victories, and new victors».

According to Coubertin, inequalities are not unjust in and of themselves. Rather, they are unjust when they are based on unfairly earned privileges and advantages. The spirit of sport, following Coubertin's ideas, is against such unfair privileges and advantages. As we have seen before, sports should be essentially fair. This sporting justice is a force that can shape the nature of our democratic spirit, so sports could be a tool to make our societies more just. As Wachter claims (2002), as we find this force within sports, we acknowledge that justice is not going to emerge automatically. However, we should learn how to modulate and utilise sports to achieve such an effect.

Thus, the idea that nothing in sport belongs to the athletes by privilege turns it into an illustration of what an open society is like. In such a society, citizens are equals among equals and, along with Coubertin, those citizens who show that they are more excellent than others -in a public, objective, and open wayshould rule the government. They deserve to be the leaders of public affairs. This is a lesson that sport teaches us. So, we can conclude that sport is politically and socially relevant in our societies. It contains many implicit features that turn it into a valuable practice in the task of bettering our world.

According to these ideas, we argue against Huizinga that modern sport still has the potential to influence and shape "serious" activities like politics and education. We acknowledge that modern sport has lost many of the ludic elements that it used to have. However, it still has many "serious" values and forces at the core of its nature. One of our main tasks as philosophers of sport is to make these values and forces more explicit and visible, to see how they shape our society, and to learn how to apply their values to our reality in order to improve it.

\section{Conclusions: Beyond the ludic sense of sport}

The starting point of this paper was the classical discussion in philosophy of sport about the ludic nature of sport. Such a debate explores whether 
or not sport, which is mainly an artificial activity created to have fun, is a "serious" activity in our society. By "serious", we include those activities which can shape people's views of the world, values, and the like. If sport does not have such a potential to shape our social reality, then it should be taken as a trivial activity.

We rejected such a trivial conception of sport. To do so, we argued that sport has always been shaping the social reality of which it was part. For instance, we showed that Greek sporting contests and the principles on which they were based were at the roots of both Greek democracy and philosophy. Moreover, we analysed the principles that these three activities (sport, politics, and philosophy) shared. In so doing, we argued that sport could still be a democratic force in our societies. We could use it as a tool to better our world. Sport is a gymnasium in which people can exercise not just their physical skills, but also their moral and communicative capacities. Thus, one of our main tasks as philosophers of sport is to understand such a democratic potential of sport in order to promote it.

\section{Agradecimientos}

Este trabajo se inscribe dentro del proyecto de investigación con referencia FFI2008-06133/FISO financiado por el Ministerio de Ciencia e Innovación. Becario de Investigación FPU (AP2009-4405) del Ministerio de Educación y Ciencia.

\section{B I B LIOG RAFÍA}

Aristotle (1959). Politics. London: Heinemann.

Arnold, P. J. (2002). Democracy, education, and sport. In A. M. Holowchak (Ed.), Philosophy of sport: Critical readings, crucial issues (pp. 484493). New Jersey: Pearson.

Brown, M. W. (1984). Paternalism, drugs, and the nature of sports. Journal of the Philosophy of Sport, 11, 14-22.

Davey, N. (2006). Unquiet understandig: Gadamer's philosophical hermeneutics. Albany: State University of New York Press.

Gadamer, H. G. (1975). Truth and method. New York: Continuum Publishing Group.

Guttman, A. (1978). From ritual to record: The nature of modern sports. New York: Columbia University Press.

Habermas, J. (1997). Modernity: An unfinished project. In M. Paserin d'Entreves \& S. Benhabib (Eds.), Habermas and the unifinished project of modernity (pp. 38-55). Cambridge: The MIT Press.

Heidegger, M. (1962). Being and time. Oxford: Basil Blackwell Publisher.

Holowchak, M. A. (2002). Moral liberalism and the atrophy of sport: autonomy, desire, and social irresponsibility. In A. M. Holowchak (Ed.), Philosophy of sport: Critical readings, crucial issues (pp. 75-84). New Jersey: Pearson.

Huizinga, J. (2005). Homo ludens. Madrid: Alianza.

Isidori, E., \& Reid, H. L. (2011). Filosofia dello sport. Roma: Bruno Mondadori-Pearson.

Jaeger, W. (1944). Paideia: the ideals of Greek culture. Vol. II: The conflict of cultural ideals in the age of Plato. New York: Oxford University Press.

Kretchmar, R. S. (2007). Dualism, dichotomies and dead ends: Limitations of analytic thinking about sport. Sport, Ethics and Philosophy, 1(3), 266-280

McNamee, M. (2008). Sports, virtues, and vices: Morality plays. New York: Routledge.

McNamee, M., \& Parry, J. (1998). Ethics and sport. London: Routledge.

Melich, J. C. (1996). Antropología simbólica y acción educativa. Barcelona: Paidós.

Miller, S. G. (2003). The organization and functioning of the Olympic
Games. In D. J. Philips, \& D. Pritchard (Eds.), Sport and Festival in the Ancient Greek World (pp. 197-292). Cardiff: Classical Press of Wales. Miller, S. G. (2004). Ancient Greek athletics. Yale: Yale Univerity Press.

Morgan, W. J. (2012). Broad internalism, deep conventions, moral entrepeneurs, and sport. Journal of the Philosophy of Sport, 39(1), 65-100.

Pawlenka, C. (2005). The idea of fairness: A general ethical concept or one particular to sport ethics. Journal of the Philosophy of Sport, 32(1), 49-64.

Philips, D. J. (2003). Athenian political history. A panathenaic perspective. In D. J. Philips, \& D. Pritchard (Eds.), Sport and festival in the ancient Greek world (pp. 197-292). Cardiff: Classical Press of Wales.

Rawls, J. (1985). Justice as fairness: Political not metaphysical. Philosophy and public affairs, 14(3), 223-251.

Reid, H. L. (2011). Athletics and philosophy in the ancient world: Contests of virtue. New York: Routledge.

Russell, J. S. (1999). Are rules all an umpire has to work with? Journal of the Philosophy of Sport, 26(1), 27-49.

Scanlon, T. F. (2002). Eros and Greek athletics. New York: Oxford University Press.

Simon, R. L. (2000). Internalism and internal values in sport. Journal of the Philosophy of Sport, 27(1), 1-16.

Simon, R. L. (2010). Fair play: The ethics of sport. Boulder: Westview Press. Tollener, J., \& Schotsmans, P. (2013). Self, other, play, display and humanity: Development of a five-model for the analysis of ethical arguments in the athletic enhancement debate. In J. Tollener et al (Eds.), Athletic enhancement, human nature and ethics (pp. 21-43). Dordrecht: Springer Netherlands.

Torres, C. R. (2011). Gol de media cancha. Conversaciones para disfrutar del deporte plenamente. Buenos Aires: Miño y Dávila Editores.

Tuncel, Y. (2013). Agon in Nietzsche. Milwaukee: Marquette University Press.

Wachter, D. F. (2002). Education for peace in sport education. In A. M. Holowchak (Ed.), Philosophy of sport: Critical readings, crucial issues (pp. 446-454). New Jersey: Pearson. 